Gitation: Arcos-Estrada, E. G., DíazRamírez, M., Jiménez-Guzmán, J., León-Espinosa, E. B., García-Garibay, M., Fabela-Morón, M. F., Rayas-Amor, A. A., Ruiz-Hernández, R., Pérez-Ruiz, R. V. \& Cruz Monterrosa, R. G. (2021). purpurascens Charpentier) paste addition on rheological behavior of Mole Poblano. Agro Productividad. https://doi. org/10.32854/agrop.v14il1.2176

Editor in Chief: Dr. Jorge Cadena Iñiguez

Received: March 13, 2021. Accepted: October 21, 2021. Published on-line: November 26, 2021.

This work is licensed under a Creative Commons Attribution-NonCommercial 4.0 International license. Effect of grasshopper (Sphenarium

\section{Effect of grasshopper (Sphenarium purpurascens Charpentier) paste addition on rheological behavior of Mole Poblano}

\author{
Arcos-Estrada, Eliza Guadalupe ${ }^{1}$; Díaz-Ramírez, Mayra ${ }^{2}$; Jiménez-Guzmán, Judith ${ }^{2}$; \\ León-Espinosa, Erika Berenice ${ }^{2}$; García-Garibay, Mariano ${ }^{2}$; Fabela-Morón, Miriam Fabela ${ }^{2}$; \\ Rayas-Amor, Adolfo Armando ${ }^{2}$; Ruiz-Hernández, Rafael ${ }^{2}$; Pérez-Ruiz, Rigoberto Vicencio ${ }^{2 *}$; \\ Gruz Monterrosa, Rosy Gabriela ${ }^{2 *}$ \\ 1 Universidad Autónoma Metropolitana, Biología Ambiental, División de Ciencias Biológicas y dela Salud, \\ Unidad Lerma. Lerma de Villada, Estado de México, G.P. 52005. \\ 2 Universidad Autónoma Metropolitana, Departamento de Ciencias de la Alimentación, División de Ciencias \\ Biológicas y de la Salud. Unidad Lerma. Lerma de Villada, Estado de México. C. P. 52005. \\ * Correspondence: r.cruz@correo.ler.uam.mx
}

\begin{abstract}
Objective: Analyze the effect of grasshopper (Sphenarium purpurascens Charpentier) paste addition on the rheological behavior of Mole Poblano (MP) and its relation with the technological properties of the grasshopper paste.

Design/methodology/approach: The addition of grasshopper paste was done at different proportions as follows: $\mathrm{T} 0=0 \%$ of grasshopper paste (GP) and $100 \%$ of mole Poblano (MP); T10 $=10 \%$ GP and 90\% MP; T15 $=15 \%$ GP and $85 \%$ MP, T20 $=20 \%$ GP and $80 \%$ MP, T25 $=25 \%$ GP and $75 \%$ MP, T30 $=30 \%$ GP and $70 \%$ MP. Water retention and emulsifying capacity of grasshopper paste were evaluated. Density, kinematic and apparent viscosity, and rheological behavior were analyzed at $25^{\circ} \mathrm{C}$; rheological parameters (consistency index $(\mathrm{k})$ and flow behavior index $(\mathrm{n})$ ) were calculated by performing a regression analysis to adjust the graphs to a power-law model.

Findings/conclusion: Grasshopper paste had higher emulsifying capability than water retention capability. Apparent viscosity of all formulations decreased as shear rate increased, so all mixtures of GP and MP demonstrated No-Newtonian behavior and pseudoplastic performance. Index consistency increased as GP content increased, these results are related with protein content because GP had a good emulsifying capability. Limitations on study/implications: More studies about the characterization of the proteins of GP and their interaction with other components are required.
\end{abstract}

Key words: mole poblano, grasshopper paste, viscosity, rheological parameters.

\section{INTRODUCTION}

Mole is a typical artisan food from México, which is a complex mixture of hot peppers ground with nuts, chocolate, oil, dry corn tortilla, and several spices in different proportions

(Alvarez-Parrilla et al., 2014; Barros, 2005), its formulation depends on the region where mole is prepared (Barros and Monteagudo, 2004). Complex processing of Mole and its wide variety of ingredients promote

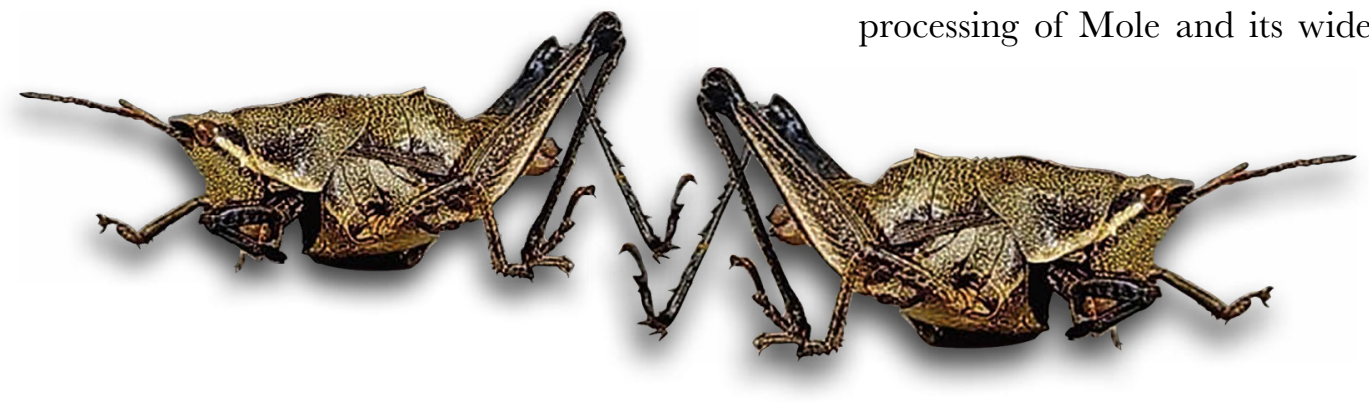
special physical properties and quality (Solís,

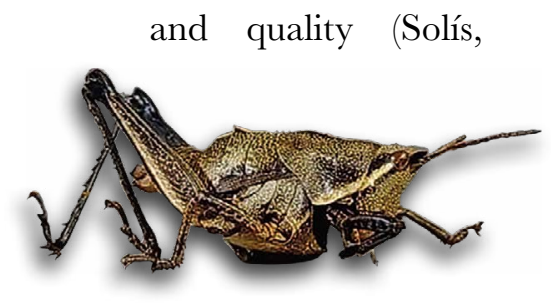


2008); paste, liquid, granule or comprised powder are the presentations of Mole in Mexican market (Hernández et al., 2017). From physic-chemical point of view, this food is a complex colloid system, where emulsion and colloid suspension are mixed; fat, carbohydrates and proteins are related to the rheological behavior an although a low protein content in mole was described (2-3\%) (Alvarez-Parrilla et al., 2014), this component could has an important technological function as hydrocolloid or emulsifier, hence the addition of protein could be considered to the improvement of the technological and rheological properties.

Edible insects are commonly consumed in México, ants, crickets, worms, beetles, grasshopper among other insects are eaten. Also, grasshopper could provide environmental, economical and social benefit by its consumption, and its composition gives nutritional advantages because of protein, vitamins and minerals content, therefore it could be added to poor nutritional foods (García et al., 2018). Regarding nutritional improvement, a previous study (Arcos-Estrada et al., 2020) showed that the mixtures of grasshopper and mole poblano increased the protein content, this fact not only could modify its nutritional quality but also the physical characteristics as apparent viscosity and rheological performance which are related to the texture, sensory analysis, handling properties and acceptance or rejection of the food (Navas, 2006), therefore the aim of this study was evaluate the effect of the grasshopper paste addition on rheological behavior of Mole Poblano and its relation with the technological properties of the grasshopper paste.

\section{MATERIALS AND METHODS}

\section{Materials}

Grasshoppers were recollected in Hidalgo State, México and all the ingredients of mole Poblano formulation were commercial.

\section{Methods}

Grasshoppers paste (GP) preparation. Grasshoppers were recollected in Hidalgo State, México. They were washed and dried in an oven at $50^{\circ} \mathrm{C}$ during $8 \mathrm{~h}, 500 \mathrm{~g}$ of insects were milled (Aragón-García et al., 2018) and the grasshopper paste was stored in freezing until their incorporation to mole Poblano.

Water retention and emulsifying capacities of the GP. These properties were evaluated according to the methods proposed by Villegas de Gante (2015); in the first analysis $5 \mathrm{~g}$ of GP was mixed with $8 \mathrm{ml}$ of $0.6 \mathrm{M} \mathrm{NaCl}$ solution, then it was cooled in an ice bath during 30 minutes after, mix was centrifuged at $10000 \mathrm{rpm}$ during 5 minutes, and finally the retained water was measured and reported. In the second analysis, $25 \mathrm{~g}$ of GP was mixed with $75 \mathrm{ml}$ of $1 \mathrm{M} \mathrm{NaCl}$ solution in a mixer during 5 minutes at lowest velocity, after that, vegetable oil was added to the mix until it does not incorporate in the GP, the incorporated oil volume was registered and reported.

Mole Poblano paste (MP) preparation. Mole Poblano paste was prepared according to the recipe from El Museo Frida Khalo, from the book Las fiestas de Frida y Diego, "Recuerdos y recetas" (Rivera-Marín, 2005) (Table 1). After, six mixtures were obtained with different proportions of GP and MP: T0 $=0 \% \mathrm{GP}$ and 100\% MP; T10 $=10 \% \mathrm{GP}$ and $90 \% \mathrm{MP} ; \mathrm{T} 15=15 \% \mathrm{GP}$ and $85 \% \mathrm{MP} ; \mathrm{T} 20=20 \% \mathrm{GP}$ and $80 \% \mathrm{MP} ; \mathrm{T} 25=25 \% \mathrm{GP}$ and 
Table 1. Formulation of mole poblano.

\begin{tabular}{l|c}
\hline \multicolumn{1}{c|}{ Ingredient } & g/100g of Mole Poblano \\
\hline Hot peppers & 34.79 \\
\hline Onion & 16.50 \\
\hline Chicken soup & 12.46 \\
\hline Lard & 9.97 \\
\hline Tomato & 6.13 \\
\hline Almonds & 4.69 \\
\hline Chocolate & 4.61 \\
\hline Bread roll and Tortillas & 2.84 \\
\hline Sesame & 2.36 \\
\hline Raisins & 2.24 \\
\hline Condiments & 1.12 \\
\hline
\end{tabular}

$75 \%$ MP; T30 $=30 \%$ GP and 70\% MP. The mixtures were stored in freezing until their analysis.

Apparent viscosity. Viscosity evaluation was done using a DV2T Brookfield viscosity analyzer. $300 \mathrm{~g}$ of the mixture was put into a glass vessel and the viscosity was evaluated at 3, 30, 60, 120 and $180 \mathrm{rpm}$ at $25^{\circ} \mathrm{C}$ (Méndez and Ramos, 2008) with the needle 7.

Density. Paste density was determined as the ratio of the weight of a standard container $\left(8 \mathrm{~g} / \mathrm{cm}^{3}\right)$ filled with GP or MP mixes at $25^{\circ} \mathrm{G}$.

\section{Data Analysis}

Three independent measurements per analysis were done. ANOVA analysis was done and the Tukey test using Minitab 17.

\section{RESULTS AND DISGUSSION}

Figure 1 shows the relation between viscosity and shear rate from different paste mixtures of GP and MP. Non-Newtonian behavior is observed in all mixtures because viscosity changed as the shear rate is modified and also showed a shear-thinning performance because their viscosity decreased as the shear rate increased. Besides, initial viscosity values (Table 1) increased as the GP protein increased until T15 treatment (15\% GP) after that, the initial viscosity values of the mixtures T20 and T25 were lower than T15 and similar between them, whereas T30 treatment had a lower value but it was bigger than the control mixture value (T0). This behavior could be attributed to the addition of GP paste because a higher protein content is presented in the mixture, and these proteins can act as hydrocolloids and emulsifiers. These technological properties were measured in the GP and results showed that it retains $0.321 \mathrm{ml}$ of $\mathrm{H}_{2} \mathrm{O}$ and $2 \mathrm{ml}$ of oil per gram, this demonstrates that GP is capable to retain oil and water, which has the property of forming viscous dispersions and/or gels and could function as thickening agents, and gelling agents in food. 

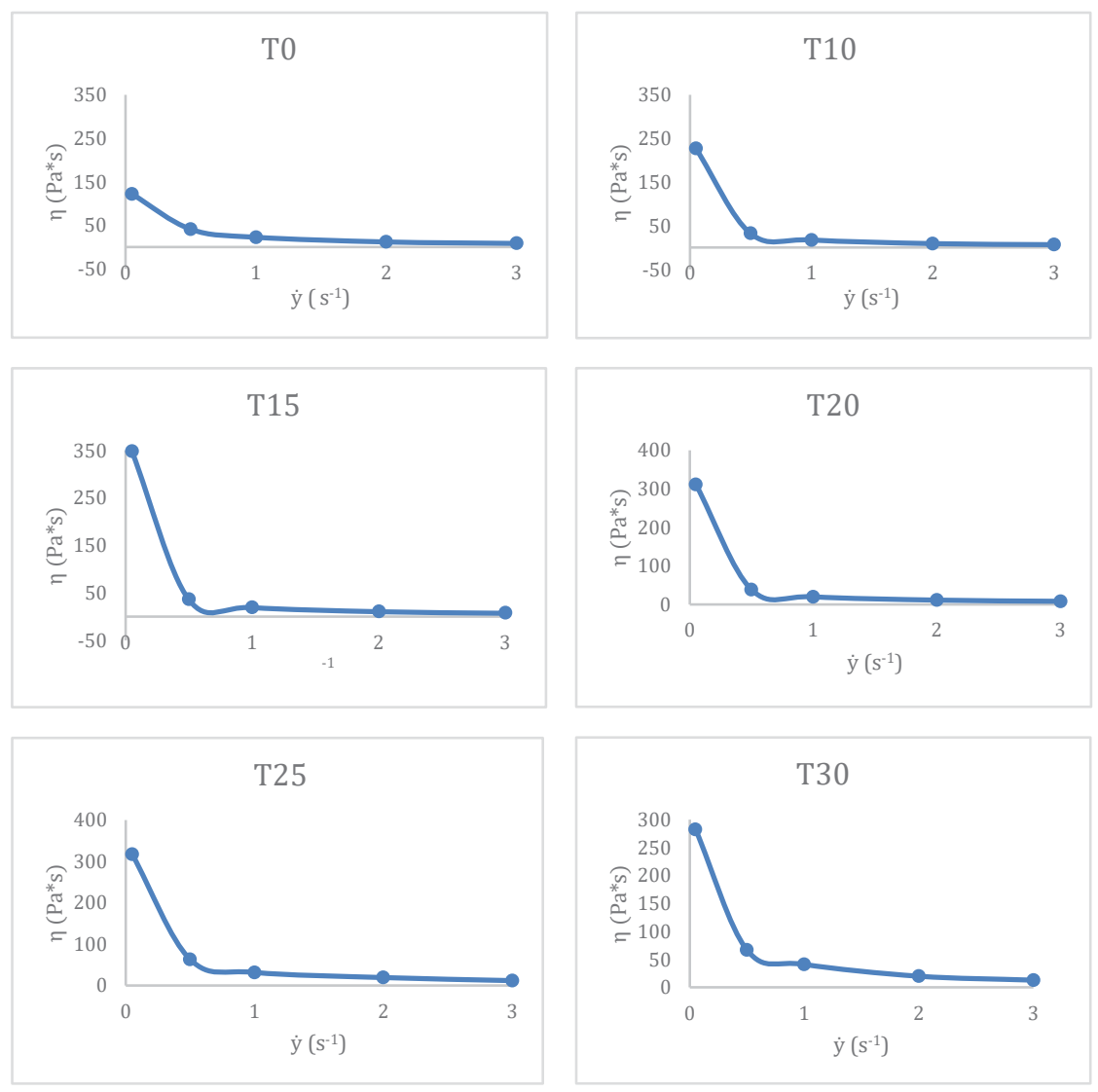

Figure 1. Relation between apparent viscosity and deformation velocity of different GP and MP mixtures at $25^{\circ} \mathrm{C}$.

Also, density values (Table 2) were higher than control except T25, these results are related to the non soluble solids of GP incorporated in the MP. Kinematic viscosity denotes the behavior of the paste as a fluid discarding the forces that generate the paste's motion and it represents better the viscosity of the static fluid, these values were higher than control and are related to the technological properties of GP (water retention and emulsifying capabilities).

On the other side, the data obtained were adjusted using the Otswald de Waele model (power model) (Eq. 1), which is used to describe to Non-Newtonian fluids, substituting the

Table 2. Density, apparent and kinematic viscosity of different GP and MP mixtures at $25^{\circ} \mathrm{C}$ at $3 \mathrm{rpm}$.

\begin{tabular}{c|c|c|c}
\hline Mixture & Density $\left(\mathbf{k g} / \mathbf{m}^{\mathbf{3}}\right)$ & Apparent Viscosity $(\mathbf{P a} \mathbf{s})$ & Kinematic viscosity $\left(\mathbf{m}^{\mathbf{2}} \mathbf{s}\right)$ \\
\hline T0 & 996.1 & 121.800 & 0.122 \\
\hline T10 & 1031.4 & 226.233 & 0.219 \\
\hline T15 & 1001.4 & 348.000 & 0.348 \\
\hline T20 & 1031.8 & 311.100 & 0.302 \\
\hline T25 & 986.5 & 317.300 & 0.322 \\
\hline T30 & 1035.8 & 282.700 & 0.273 \\
\hline
\end{tabular}


viscosity equation (Eq. 2) in equation 1, we obtained a relation between apparent viscosity and shear rate (Eq. 3) in order to obtain the index consistency (k) values and flow behavior index (n). The last model was linearized using equation 4 (Eq. 4) (Talens Oliag, 2016).

$$
\begin{array}{cc}
\sigma=K \dot{y}^{n} & \text { Eq. } 1 \\
\eta=\sigma / \dot{y} & \text { Eq. } 2 \\
\eta=K \dot{y}^{n-1} & \text { Eq. } 3 \\
\ln \eta=\ln K+(n-1) \ln \dot{y} & \text { Eq. } 4
\end{array}
$$

Figure 2 shows a linearized curve of the all treatments and Table 3 shows the values of the consistency $(\mathrm{k})$ and flow behavior index $(\mathrm{n})$, where the all $\mathrm{n}$ values were lower than 1. The $\mathrm{n}$ value indicates if a fluid is near to the Newtonian behavior $(\mathrm{n}>1$ is dilatant fluid, $n=1$ is Newtonian fluid and $n<1$ is pseudoplastic fluid) (Icarte, 2002). Different mixtures of GP an MP pastes had n values lower than 1 showing a Non-Newtonian and
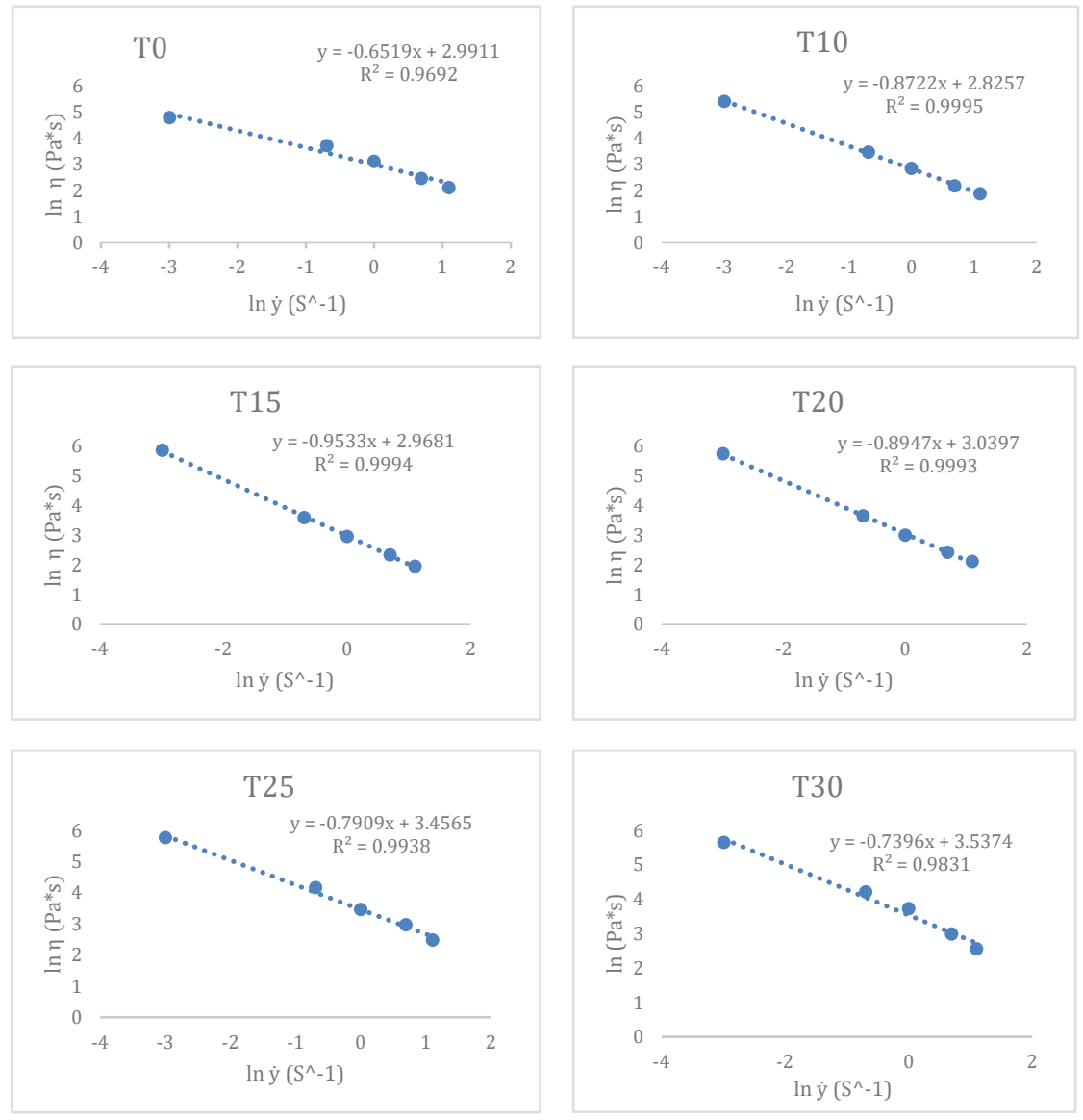

Figure 2. Linearized curves of the relation between apparent viscosity and shear rate of different GP and MP mixtures at $25^{\circ} \mathrm{C}$. 
Table 3. Consistency and behavior indexes of different GP and MP mixtures at $25^{\circ} \mathrm{C}$.

\begin{tabular}{c|c|c}
\hline Treatment & K & $\mathbf{n}$ \\
\hline T0 & 19.907 & 0.348 \\
\hline T10 & 16.872 & 0.128 \\
\hline T15 & 19.455 & 0.047 \\
\hline T20 & 20.899 & 0.105 \\
\hline T25 & 31.706 & 0.209 \\
\hline T30 & 34.377 & 0.260 \\
\hline
\end{tabular}

a pseudoplastic behavior, these results are according to other foods as honey (GómezDíaz et al., 2004), fruit puree (Miranda et al., 2011; Cardoso de Oliveira et al., 2012), and mayonnaise (Agueroa, 2016). Different factors influence the behavior index as content of ingredients, temperature, and particle size (Osorio, 2018). Mole is a complex mixture of different ingredient which have different technological functions that affect the viscosity and rheological behavior. The addition of GP paste increased the protein and polysaccharide contents and affect the $n$ values of the mixtures. The values of the consistency coefficient $(\mathrm{k})$ (Table 3) increased when the GP paste addition was increased, this indicates a lower ability of paste to flow when a higher content of GP paste is in the mixture. Similar values are observed in fruit pulps as mango (Ortega Quintana et al. (2015), and in fruit juices (Chin et al., 2009; Quek et al., 2013).

\section{GONGLUSIONS}

GP had higher emulsifying activity and water retention capacity, these technological properties were related to higher apparent and kinematic viscosity values of MP and GP mixes. Mole poblano added with grasshopper pastes had a Non-Newtonian and a pseudoplastic behavior.

\section{REFERENCES}

Agueroa, C. M. (2016). Viscosidad de una salsa de Tarwi (Lupinus mutabilis) libre de Gluten y lactosa utilizando gomas Guar y Xantan. Revista de Investigaciones de la Universidad Le Cordon Bleu, 3(1), 29-40.

Aragón-García, A.; Rodríguez-Lima, D.R.; Pino-Moreno, J.M.; Aragón-Sánchez, M.; Carlos-Ángeles, S. y García-Pérez, A. (2018). Valor nutritivo de la harina de chapulín (Sphenarium purpurascens Charpentier) tostado o natural. Entomología mexicana, 5, 106-112. http://www.socmexent.org/entomologia/ revista/2018/BHN/BHN\%20106-112.pdf

Barros, C. y Monteagudo J.L.C. (2004). El mole. Aportaciones prehispánicas y Construcción y evolución del mole virreinal, en El mole en la ruta de los dioses. 6to Congreso sobre Patrimonio Gastronómico y Turismo Cultural (Puebla 2004). Memorias. México, Patrimonio Cultural y Turismo, Cuadernos, no. 12, pp. 11, 21, 34. [en línea]

Cardoso de Oliveira, Ricardo, \& Rossi, Robson Marcelo, \& Davantel de Barros, Sueli Teresa (2012). Estudo reológico da polpa de morango (Fragaria vesca) em diferentes temperaturas. Acta Scientiarum. Technology, 34(3), 283-288. [fecha de Consulta Junio de 2020]. ISSN: 1806-2563. Disponible en: https://www. redalyc.org/articulo.oa?id=3032/303226542005

Chin, NL, Chan, SM, Yusof, YA, Chuah, TG y Talib, RA (2009). Modelado del comportamiento reológico de concentrados de jugo de pomelo utilizando una curva maestra. Revista de ingeniería alimentaria, 93(2), 134-140. 
Gómez-Díaz, D., Navaza, J. M., \& Quintáns-Riveiro, L. C. (2004). Estudio viscosimétrico preliminar de mieles de bosque denominación específica "miel de galicia" viscosimetric study of multifloral honeys with specific guarantee "miel de galicia" estudo viscosímetrico de meles de bosque denominación específica "mel de galicia”. CYTA-Journal of Food, 4(4), 234-239.

Hernández, C. S., Hernández, M. Á. S., Montiel, L. G., \& Pinacho, A. J. V. (2017). Capítulo 15. Propiedades fisicoquímicas del mole negro de Oaxaca. Índice, 188.

Icarte, R. M. (2002). Caracterización del comportamiento reológico de sopa de crema orientada a control de calidad. Valdivia, Chile.

Méndez, A. R., \& Ramos, O. A. N. (2008). Comportamiento reológico de un fluido. Universidad del Mar. Oaxaca, México. Pág, 1-2.

Miranda, V.A.M. \& Queiroz, Alexandre \& Maria Feitosa de Figueirêdo, Rossana \& Santos, Dyego. (2011). Viscosidade aparente de polpas de graviola com diferentes concentrações. Revista Brasileira de Produtos Agroindustriais. 13. 363-374. 10.15871/1517-8595/rbpa.v13n4p363-374.

Navas, J. S. (2006). Fundamentos de reología de alimentos.

Ortega Quintana, F. A., Salcedo Galván, E., Arrieta Rivero, R., \& Torres Gallo, R. (2015). Efecto de la temperatura y concentración sobre las propiedades reológicas de la pulpa de mango variedad Tommy Atkins. Revista Ion, 28(2), 79-92.

Quek, M. C., Chin, N. L., \& Yusof, Y. A. (2013). Modelling of rheological behaviour of soursop juice concentrates using shear rate-temperature-concentration superposition. Journal of Food Engineering, 118(4), 380-386.

Quirce Vázquez, G., Filippini, V., \& Micó, E. (2013). La utilización de los insectos en la gastronomía, un taller nutritivo.Cuadernos de biodiversidad. 43.10.14198/cdbio.2013.43.02.

Rivera-Marín, G. (2005) Las fiestas de Frida y Diego. Recuerdos y recetas. Promexa, México, p.214.

Solís, Y. (2008). Evaluación Sensorial: Selección de Jueces (Doctoral dissertation). Instituto Politécnico Nacional. Unidad Profesional Interdisciplinaria de Biotecnología. México DF).

Talens Oliag, P. (2016). Caracterización del comportamiento reológico de un alimento fluido pseudoplástico. 